\title{
Determinants of Livestock Production Development of Smallholder Farmers'
}

\author{
${ }^{* 1}$ AMENU LETA DUGUMA; ${ }^{2}$ JIREGNA KENEA DEBSU
}

\author{
${ }^{1}$ Department of Agricultural Economics, Ambo University, Ambo, Ethiopia \\ ${ }^{2}$ Department of Agricultural Economics, Mettu University, Bedele, Ethiopia \\ *Corresponding Author Email: amenuleta@gmail.com
}

\begin{abstract}
The study assessed determinants of livestock production development of smallholder farmers' through identifying the constraints and opportunity to livestock production developments. The study adopted cross sectional survey design. The district was randomly selected from zones. A total of 99 respondents were selected from the kebele where by ten were female headed and 89 were male headed households. Descriptive statistics result showed that opportunities of livestock production development in the study area, availability of water, availability of market information, supply of improved breed, feed availability, credit services, veterinary services and mixed crop-livestock production system. Multiple linear regression analysis has been carried out to find out determinants of livestock production development of smallholder farmers'. The results of the multiple linear regression model showed that from a total of ten explanatory variables were included in the model, of which availability of grazing land, extension services, artificial insemination and veterinary service, availability of market information and education level were found to be statistically significant to livestock production development at $1 \%$, and $5 \%$ significant level respectively.
\end{abstract}

\section{DOI:https://dx.doi.org/10.4314/jasem.v23i8.18}

Copyright: Copyright $(\mathrm{C} 2019$ Amenu and Jiregna. This is an open access article distributed under the Creative Commons Attribution License (CCL), which permits unrestricted use, distribution, and reproduction in any medium, provided the original work is properly cited.

Dates: Received: 17July 2019; Revised: 18 August 2019; 28 August 2019

Keywords: Determinants, Livestock Production Development, Multiple Linear regressions Model

Agriculture sector is plays a vital role in the economy of the country, It accounts for $43 \%$ of GDP, $85 \%$ of employment and $70 \%$ of export earnings (UNDP, 2013). It has a substantial contribution to Ethiopian economy in terms of generating employment opportunity, product contribution, market contribution, factor contribution, balance of payment contribution, welfare contribution and environmental contribution. Moreover, the country does have huge potential for agricultural development in general and livestock subsector in particular (World Bank, 2009). Ethiopia is home to Africa's largest livestock population, and it is the continent's top livestock producer and exporter. Although domestic demand for animal products in Ethiopia is increasing driven by the urban middle and upper-classes export potential is the key force encouraging expansion and intensification of livestock production MacDonald M., et al., (2011). According to the results Central statically Agency (2016) reveal that the recent livestock population of Ethiopia estimates that the country has about 57.83 million cattle, 28.89 million sheep, 29.70 million goats, 2.08 million horses, 7.88 million donkeys, 60.51 million poultry, 5.92 million beehive, 0.41 million mules and about 1.23 million camels. They are an important component of nearly all farming systems in Ethiopia and provide draught power, milk, meat, manure, hides, skins and other products Funk C., et al.,
(2012).According to the results of a base line survey report by Central statically Agency (2013) despite the country has huge potential to produce livestock there are a chronic challenges of livestock production development in most part of the country. As different studies highlighted that livestock production and the productivity is proportionally lowered by various livestock management problems, prevalence of major endemic diseases, poor feeding and high stocking rate on grazing lands, lack of support services such as extension services, veterinary services, insufficient data to plan improved services and inadequate information on how to improve animal breeding, marketing, and processing Kedija et al., (2008). Brahmi and Thakur, (2011) reported that lack of awareness, illiteracy, poor economic statues, lack of faith in government programs, lack of disease prevention program, village politics and subsidy culture affect the peoples participation to a large extent livestock production.

Mtero et al. (2012) reported that currently number of livestock production found to be decline in rural areas. According to study by Lakew Desta et al., (2000) reported that inadequate feed both in quantity and quality, widespread diseases and poor health, poor genetic potential for production traits and inadequate or inappropriate livestock policies with respect to credit, extension, marketing and infrastructure have 
been listed as major factor affecting the development of the livestock sub-sector in most highland parts of the country. In addition, not enough information is available on the determinant factors and opportunities of livestock production development in Bedele district in particular where livestock are considerably important to the livelihood for growing population. This study mainly concerned to identification of determinant factors influencing development of livestock among smallholder farmers in the study area.

Smallholder farmers' are rearing and consuming livestock domestically. Therefore, the government through its research organizations supply different Agricultural technology to the community and others has deliberately developed artificial insemination technology, provided extension services up to community levels throughout the entire country, removed disease problem on livestock production. Despite those mentioned efforts done by the government, livestock production development has remained low to the extent of trailing in the study area. Identification of determinant factor affecting livestock production development is preconditions for designing suitable livestock production development strategies in the future improvement of the livestock production in the study area and elsewhere in the Ethiopia. The study generally aimed at assessing determinants and opportunity to livestock production development of smallholder farmers' through measuring elasticity of different inputs used in the production of livestock.

\section{MATERIALS AND METHODS}

Study Area: The study was conducted in Bedele district of Bunno Bedele Zone, Oromia Regional state during 2018/19. It is bordered by the Sigmo Woreda, Jimma Zone on the south Western, Chora Woreda in the Northwest, Arjo Woreda in the Northern, and by the Gechi Woreda in the east. The woreda is located in the south western part of Ethiopia. It has a total area of $2,210.16 \mathrm{~km}^{2}$ with 41 rural and 2 unban kebele total 43 kebeles. The woreda has a total population of 152,675 people out of which 75,698 and 71,977 are male and female respectively and 14270 household heads out of which 12856 male and 1414 female house hold head. Furthermore, $94.8 \%$ of the population lives in rural area and $5.2 \%$ lives in urban area. The population density of the study area is 534.3 persons per kilometer square. Mixed farming (crop production and livestock rearing) is the predominant sources of livelihood for the majority of the population in the area. Geographically, the woreda falls between $36^{\circ} 00^{\prime} 0^{\prime \prime}$ up to $28^{\circ} 80^{\prime} 0^{\prime \prime} \mathrm{N}$ latitude and $20^{\circ} 79^{\prime} \mathrm{E}$ longitude. The woreda receives an average annual rainfall ranging from about 887 up to $1,194 \mathrm{~mm}$, altitude 1500 up to 2100 and temperature 18 up to 30 Centigrade. The landscape includes valley, high forests and plain divided by valleys. The woreda has $45 \%$ arable land or cultivable land (57\% was under annual crops), 4.7\% pasture land, $35 \%$, and $12 \%$ is considered swampy and degraded or otherwise unusable land respectively. Maize is an important food crop and Coffee is as important cash crop for this woreda; over 3000 hectares are planted with this crop Central Statically Agency (2013).

Sampling Techniques: Two stage sampling procedure was employed. In the first stage, Bedele district was randomly selected supposing similar livestock production development potential in the zonal as information obtained from zonally agricultural office. In the second stage, a total of 3 kebeles was randomly selected from the complete list of total kebeles of the district based on probability proportionate to total kebeles of study area. A total of 99 representative farm household was randomly selected based on probability proportionate to the population of the respective kebele.

Sample size Determination: The simplified formula provided by Yamane (1967) was used to determine the required sample size at $95 \%$ confidence level, degree of variability $=0.5$ and level of precision $(\mathbf{e})=10 \%$ are recommended in order to get a sample size which is represent a true population.

$\mathrm{n}=\frac{\mathrm{N}}{1+\mathrm{N}(\mathrm{e})^{2}}=\frac{14270}{1+14270(0.1)^{2}}=99$

Where: $\mathbf{n}=$ is the representative sample size, $\mathbf{N}=$ is the total households head in the district $(\mathrm{N}=14270)$ and $\mathbf{e}$ $=(10 \%)$ is the level of precision defined to determine the required sample size at $95 \%$ confidence level.

Method of Data Analysis: Both descriptive statistic and econometric model was used to analyze the collected data. Descriptive statistic table, percent and frequency was used to describe the socio- economic data and available opportunities to livestock production while the econometric analysis has apply the multiple linear regression model to identify determinants of livestock production development.

Model Specification: Number of livestock owned by sampled household head is continuous dependent variable of the model that is measured in Tropical Livestock Unit (TLU). The appropriate econometric technique to deal with continuous dependent variable is using multiple linear regression models and it is the most popular statistical techniques used to analysis the 
data. It is a general statistical technique through which one can analyze the relationship between a continuous dependent variable and a set of dummy/categorical/ continuous independent variables.

$$
y=\beta_{1} \chi_{1}+\beta_{2} \chi_{2}+\beta_{3} \chi_{3}+\beta_{4} \chi_{4} \ldots \ldots+u i
$$

Where, $y=$ Number of livestock owned by sampled household head in TLU; $X_{1}=$ Age of respondent measured in year; $X_{2}=$ Education level of respondents measured in number of year spend in schooling; $X_{3}=$ availability of veterinary services $(0=$ no veterinary services, $1=$ if veterinary services); $X_{4}=$ Availability of infrastructure $(0=$ if no infrastructure, $1=$ if there is infrastructure); $X_{5}=$ Availability of Artificial Insemination $(0=$ if no artificial insemination, $1=$ if there); $X_{6}=$ Availability of grazing land ( $0=$ if no grazing land, $1=$ if grazing land); $X_{7}=$ availability of extension services $(0=$ if no extension services, $1=$ otherwise); $\mathrm{X}_{8}=$ Availability of market information $(0=$ if no market information, $1=$ otherwise); $\mathrm{X}_{9}=$ Capital household head have for livestock production in birr

\section{RESULT AND DISCUSSION}

Type and Number of livestock owned by sampled respondents: In this study, the majority of survey respondents 90 percent of them keep livestock and these include cattle, ruminants/shoats such as goats and sheep, and equines, and donkeys. Survey results indicate that farmers in the study area have livestock in Tropical Livestock Unit(TLU) are 511TLU, 28.75TLU, 78.75TLU, 127TLU, 4.03TLU, 25.6TLU, and 57.4TLUof cow, calf, heifer, oxen, sheep, goat, and donkey respectively in the study area.

Table1: Description of total livestock production owned sampled

\begin{tabular}{lll}
\multicolumn{3}{c}{ respondents } \\
\hline Livestock type & Number & TLU \\
\hline Cow & 511 & 511 \\
Calf & 115 & 28.75 \\
Heifer & 105 & 78.75 \\
Oxen & 127 & 127 \\
Sheep & 197 & 25.6 \\
Goat & 31 & 4.03 \\
Donkey & 82 & 57.4 \\
Poultry & 76 & 23.4 \\
\hline
\end{tabular}

Opportunity of livestock Production: According to the survey results show that there are a major opportunities identified to livestock production in the study area. Out of 99 respondents in the study area $27.27 \%$, reported availability of veterinary services, and $25.25 \%$ of them reported availability of water, $22.22 \%$ of respondents reported that availability of mixed crop system, $20.2 \%$ of respondents reported that availability market, $13.13 \%$ of respondents report that supply of credit service, and $12.12 \%$ of feed availability were the major opportunities for livestock production development in study area.

\begin{tabular}{|c|c|c|c|}
\hline \multirow[t]{2}{*}{ Opportunity to Livestock Production } & \multicolumn{2}{|c|}{ Respondents } & \multirow[t]{2}{*}{ Rank } \\
\hline & Number & Percent & \\
\hline Availability of Water & 25 & 25.25 & $2^{\text {nd }}$ \\
\hline Availability of Feeding resources & 12 & 12.12 & $6^{\text {th }}$ \\
\hline Availability of Veterinary services & 27 & 27.27 & $1^{\text {st }}$ \\
\hline Availability of Mixed crop system & 22 & 22.22 & $3^{\text {rd }}$ \\
\hline Availability of Credit service & 13 & 13.13 & $5^{\text {th }}$ \\
\hline Supply of Improved breed & 11 & 11.11 & 7 th \\
\hline Availability of Market & 20 & 20.2 & $4^{\text {th }}$ \\
\hline
\end{tabular}

Determinants of Livestock Production Development: Before fitting this model, the problem of multicollinearity among independent variables was checked by using coefficient contingency (CC). The term Multicollinearity is due to Ragnar Frisch, originally it meant the existence of perfect or exact linear relationship among some or all explanatory variables of multiple linear regression model. The problem of multicollinearity was not serious among variables because of coefficient of contingency value are less than 0.5 . The coefficient of determination (R2) values is 0.7966 . It means that about $79.66 \%$ of the variation in the dependent variable is explained by the independent variables, indicating relatively high explanatory power (goodness of fit) of the model. Out of these Nine explanatory variables, only 6 variables are found to be significantly affecting' household livestock production development. Those variables which are considered as important determinants of livestock development as per the analysis result are (Education level, Extension service, grazing land, veterinary service, market information and artificial insemination) are statistically significant at different significance level.

Availability of artificial insemination: The result shows that availability of artificial insemination significantly determines livestock production development of households. As the artificial insemination performed the livestock production 
development of households increased by 0.24 percent. The study supported by the finding Ramesh Ch. et al., (2008): livestock sector composition and factors affecting its growth in Ethiopia.

Availability of grazing land: The result show that presence of grazing land is positively determines livestock production development of household heads. Other factors being constant as availability of grazing land increases by one hectare, livestock production development increases by 2.572 units. This is true as farmers have more grazing land and more likely to produce livestock and sufficient grazing resources will be initiate farmers to have more number of livestock. The study supported by study done Zander et al. (2012:4) farmers mentioned land availability as the major constraint to livestock development. Land availability determines the amount of feed the livestock get therefore it is very important in livestock development Mucuthi and Munei, (2015) also indicated that the lack of water and grazing land were amongst one of the hindering factors in livestock development.

Availability of veterinary service: As availability of veterinary service increases, livestock production development of smallholder farmer increase by 0.074 percent. The implication of the analysis result show that veterinary service is an input for the health of livestock production hence increases number of livestock production. The study supported by the finding of Belay et al.,(2013:4) in Ethiopia lack of veterinary services has led to farmers using traditional medicines and these were reported to be functioning poorly.

Education level of household head: education level negatively and significantly determines livestock production development of smallholder farmers in the study area. As education level of the farmers increase, livestock number household head owned decrease by 0.074 percent. This is true as education level of farm household increase more focus on quality rather than quantity.

Availability of extension services: the estimated coefficient of this variable supports the proposed hypothesis and it is significant. Other being constant one unit increase in extension contact livestock production development increases by 2.522 units. This is true by expanding and encouraging the household participation rate for the use of extension program is still important for the livestock production enhancement since the extension user households are more productive than non-user. A study supported by the FAO (1999:28) revealed that government extension services have generally failed to provide information to individual farmers as they saw the task to be too large Mureithi and Mukiria (2015:4) mentioned that farmers ranked extension advice for government, training, and veterinary services as one of the problems they are facing; only $5 \%$ of farmers mentioned that they had access to government veterinary services and most of them relied on private veterinary services.

Access to marketing information: As household access to market information is increases, livestock production of smallholder farmer increase by 0.034 percent.The study supported by Zander et al., (2013:13) mentioned that marketing is one of the issues that most seriously impede livestock development in Africa. Marketing should play an important role in the process of transforming smallscale farmers into commercial producers; according Coetzee et al.,(2005:4) the market is the institution that should provide the necessary incentives for farmers to increase their income.

\begin{tabular}{lll}
\hline Variables & Coefficient & $P$-value \\
\hline Constant & 2.8541 & 0.0023 \\
EduHH & -0.074 & 0.075 \\
Veterinary services & 0.0743 & 0.074 \\
Infrastructure & 1.5696 & 0.736 \\
Artificial insemination & 0.2374 & 0.000 \\
Capital & 0.2125 & 0.337 \\
Age HH & 0.2383 & 0.690 \\
Grazing land & 2.572 & 0.000 \\
Extension services & 2.522 & 0.000 \\
Market information & 0.034 & 0.036 \\
Important Statistics: & & \\
Number of observation & $=99$ & 0.0000 \\
R-squared & $=0.7966$ & \\
Adjusted R-squared & $=0.7655$ & \\
\hline
\end{tabular}

Table 3: Multiple Linear Regression Model result of Determinants of Livestock Production Development

Conclusion: In conclusion, this research work aimed to identify opportunities and determinants of the livestock production development of smallholder farmers in rural areas of Bedele district. The study has employed Multiple Linear regression model. In the model number of livestock house hold head have were taken as dependent variable and ten explanatory variables were included. The result of the multiple linear regression models, show that six of the explanatory variables were found significant determinants of livestock production development of smallholder farmers; of which artificial insemination, Spread of extension services, Educational level, expansion of veterinary facilities, Market information and Availability of grazing land in the study area so that it must be give carry for those resources. The opportunities availability for livestock production are availability of water, Availability of market information, supply of improved breed, feed 
availability, credit services, veterinary supply and mixed crop-livestock production system. These findings could serve as a bench mark for further investigation to other determinant factor important for livestock production and to use available opportunity for livestock production in the study area. To this end therefore, farmers and government can give attention for protecting grazing land, dissemination of artificial insemination, Spread of extension services and expansion of veterinary facilities since it is determinant factor for livestock production development.

Acknowledgements: The authors are grateful thanks to the District livestock and Veterinary Officer of Bedele District for allowing us to use the data and Development agent full cooperation during data collection.

\section{REFERENCES}

Alemayehu M. (1985). Feed resources in Ethiopia. PP.35. In: Animal feed resources for small scale livestock producers, Proceedings of the second PANESA workshop, held in Nairobi, Kenya, 1115 November 1985.

Alemayehu M. (2002). Forage Production in Ethiopia: A Case Study with multiplications for Livestock Production. Ethiopian Society of Animal Production (ESAP), Addis Ababa, Ethiopia.

Alemayehu M. (2005). Feed resources base of Ethiopia: Status limitations and opportunities for integrated development. In: Proceedings of the 12th Annual Conference of the Ethiopian Society of Animal Production (ESAP) held in Addis Ababa, Ethiopia, August 12-14, 2004. Addis Ababa, Ethiopia.

Ayelesolomon, Assegid Workalemahu, M.A. Jabar M.M. Ahmed and Belachew Hurissa (2003). Livestock marketing in Ethiopia.

Aynalem, H., Workneh, A., Noah, K., Tadelle, D. and Azage, T. (2011). Breeding strategy to improve Ethiopian Boran cattle for meat and milk production. Improving productivity and marketing success of Ethiopian Farmers. Project Working Paper 26. ILRI (International Livestock Research Institute), Nairobi, Kenya.

Belaynesh, D. (2006). Floristic Composition and Diversity of the Vegetation, Soil Seed Bank Flora and Condition of the Rangelands of the Jijiga Zone, Somali Regional State, Ethiopia. MSc. Thesis, Alemaya University, Dire Dawa, Ethiopia.
Belete, A., Azage, T., Fekadu, B. and Berhanu, G. (2010). Cattle milk and meat production and marketing systems and opportunities for market orientation in Fogeraworeda, Amhara region, Ethiopia. (IPMS) Improving Productivity and Marketing Success 51 of Ethiopian Farmers.

Brahmi MK, Thakur KS. (2011). Factors affecting people participation in Hariyali project under Nalagarh block of Himachal Pradesh. J. Farm Sci. 1(1):105-111.

Catley A, Alders RG, Wood JLN, (2012). Participatory epidemiology: Approaches, methods, experiences. The veterinary journal, 191:151-160.

CSA (Central Statically Agency)(2013). Agricultural sample survey 2009/10 volume II Report on livestock and livestock characteristics.

CSA (Central Statically Agency)(2016). Agricultural Sample Survey. Report on Livestock and livestock characteristics (Private peasant holdings). Statistical Bulletin 2: 194.

Enaami, M., S. A. Ghani and Z. Mohamed (2011). Multicollinearity Problem in Cobb_Douglas Production Function. Journal of applied science.

FAO (2009). The state of food and agriculture. Livestock in the balance. FAO, Rome

Firew T. (2007). Evaluation of alternative feed resources for ruminants under arid zones of the tropics and sub-tropics: the case of cactus pear (Oppuntiaficus-indica) in Ethiopia. Ph.D. Thesis. Humboldt University of Berlin, Germany.

Funk C, Rowland J, Eilerts G, Emebet K, Nigist B, et al. (2012). A climate trend analysis of Ethiopia. USGS

Gujarati, D. (2003). Basic Econometrics.4th edition, New Delhi, Graw-Hill Publishers.

Haldernan Michael (2004). The political economy of the pro-poor livestock policymaking in Ethiopia, PPLPI working paper.no.19, FAO.

Heffernan, C. (2004). Livestock and the Poor: Issues in poverty focused livestock development. In responding to the Livestock Revolution: the role of globalization and implications for poverty alleviation. British Society of Animal Science, publication 33. University of Reading, United Kingdom.

IBC (Institute of Biodiversity Conservation), (2004). The state of Ethiopia's Farm Animal Genetic Resources: A contribution to the first report on the 
state of the world's animal genetic resources. May 2004, Addis Ababa, Ethiopia. 90p.

Ibrahim, H. and Olaloku, E., (2002). Improving cattle for milk, meat and traction, Manual

IFAD (2004): Livestock Services and the poor. Rome, Italy: International Fund for Agricultural Development.

Jost CC, Mariner JC, Roeder PL, Sawitri E, Macgregor-Skinner GJ (2007). Participatory epidemiology in diseases surveillance and research. Rev Sci Tech Off Int Epiz, 26(3):537549.

Kebreab, E., Smith, T., Tanner, J. and Osuji, P. (2005). Under nutrition in smallholder ruminant production system. Department Agriculture, University of Reading, U.K. (ILRI) International Livestock Research Institute.

Kedija, H., Azage, T., Mohammed, Y. and Berhanu, G. (2008). Traditional cow and camel milk production and marketing in agro-pastoral and mixed crop-livestock systems: The case of Mieso District, Oromia Regional State, Ethiopia. (IPMS) Improving Productivity and Market Success of Ethiopian Farmer, Project Working Paper, 13. ILRI (International Livestock Research Institute), Nairobi, Kenya. 56:1-3.

Lakew Desta, MenaleKassie, S. Benins and J. Pender, (2000). Land degradation and strategies for sustainable development in Ethiopian highlands: Amhara region. ILRI Socio-economic and policy research. Working paper 32. International Livestock Research Institute (ILRI)
MacDonald M, Simon J (2011). Climate, food security, \& growth Ethiopia's complex relationship with livestock.Policy Brief 3.Brighter Green.

MoA (Ministry of Agriculture). (1997). Ruminant Livestock Development Strategy, Addis Ababa. $87 \mathrm{p}$.

Mohammed Mussa (2004). A Comparative Study of Pastoralist Parliamentary Groups: Case Study on the Pastoral Affairs Standing Committee of Ethiopia, for the NRI/PENHA Research Project on Pastoralist Parliamentary Groups, funded by DFID's Livestock Production Program and the CAPE Unit, AU-IBAR, Addis Ababa, Ethiopia

Perry BN, Sones AP, Stevens KC (2005). An appropriate level of risk: balancing the need for safe livestock products with fair market access for the poor (Pro-Poor Livestock Policy Initiative.

Rushton J (2009). The economics of animal health and production. CAB International, Oxford SalesBaptista E, Lamy E, Mau M, Capela e Silva F, Coelho AV (2009) Variation in salivary protein composition related to feeding behaviour and its ecological implications. In: Zhang W, Liu H (eds) Behavioral and chemical ecology. Nova Science Publishers, Haupagge.

United Nation Development Program (UNDP, 2013). The $3^{\text {rd }}$ Annual report of Ethiopian United nation development program.

Yamane T. (1967). Statistics: An introductory Analysis, 2nd Ed:New York. 